\title{
Getting patient blood management Pillar 1 right in the Asia-Pacific: a call for action
}

\author{
Hairil Rizal Abdullah ${ }^{1, *}$, MBBS, MMed, Ai Leen $\underline{A n g}^{2, *}$, MRCP, FRCPath, Bernd Froessler $^{3, *}$, MD, PhD, \\ Axel Hofmann ${ }^{4,5,6, *}$, Dr. rer. medic., ME, Jun Ho Jang ${ }^{7, *}$, MD, PhD, Young Woo Kim ${ }^{8, *}$, MD, PhD, Sigismond $\underline{\operatorname{Lasocki}}^{9, *}$, MD, PhD, \\ Jeong Jae $\underline{L e}^{10, *}$, MD, PhD, Shir Ying Lee ${ }^{11, *}$, MBBS, FRCPath, Kar Koong Carol Lim ${ }^{12, *}$, MFM Fellow, MMed, \\ Gurpal Singh ${ }^{13,14, *}$, FRCSEd, Donat $R \underline{\text { Spahn }}^{4, *}$, MD, FRCA, Tae Hyun $\underline{U m}^{15, *}$, MD, PhD; \\ the Asia-Pacific PBM Expert Consensus Meeting Working Group
}

Preoperative anaemia is common in the Asia-Pacific. Iron deficiency anaemia (IDA) is a risk factor that can be addressed under patient blood management (PBM) Pillar 1, leading to reduced morbidity and mortality. We examined PBM implementation under four different healthcare systems, identified challenges and proposed several measures: (a) Test for anaemia once patients are scheduled for surgery. (b) Inform patients about risks of preoperative anaemia and benefits of treatment. (c) Treat IDA and replenish iron stores before surgery, using intravenous iron when oral treatment is ineffective, not tolerated or when rapid iron replenishment is needed; transfusion should not be the default management. (d) Harness support from multiple medical disciplines and relevant bodies to promote PBM implementation. (e) Demonstrate better outcomes and cost savings from reduced mortality and morbidity. Although PBM implementation may seem complex and daunting, it is feasible to start small. Implementing PBM Pillar 1, particularly in preoperative patients, is a sensible first step regardless of the healthcare setting.

Keywords: anaemia, Asia Pacific, iron deficiency, patient blood management, preoperative

\section{INTRODUCTION}

Anaemia is a global health problem, affecting $30 \%$ of the world's population in $2015 .{ }^{(1)}$ In 2010, there were 68.4 million years lived with disability from anaemia worldwide, and $56 \%$ of these were in Asia-Pacific countries. ${ }^{(2)}$ Anaemia, which is characterised by a decrease in total red blood cell (RBC) mass, is accompanied by reduced haemoglobin $(\mathrm{Hb})$ levels and altered $\mathrm{RBC}$ morphology. As its symptoms are nonspecific and develop gradually, it often goes unnoticed and therefore untreated. Iron deficiency (ID) is the most common cause of anaemia $(>50 \%){ }^{(2)}$ manifesting in decreased production of $\mathrm{Hb}$ and activity of iron-dependent enzymes. ${ }^{(3)}$ Iron deficiency anaemia (IDA) often presents in young children and pregnant women in developing countries due to malnutrition, multiparity, postpartum haemorrhage and infectious diseases; and in the elderly due to bleeding from gastrointestinal conditions. $^{(4)}$

Preoperative anaemia represents a significant healthcare problem in Asia-Pacific countries. ${ }^{(5-8)}$ This is compounded by the limited supply of blood products: 19 (23\%) out of 82 countries with low donation rates ( $<10$ donations per 1,000 population) are in the Asia-Pacific. ${ }^{(9)}$ These are typically developing countries with growing populations and a high demand for transfusions. ${ }^{(10)}$
Their blood services also face difficulties in safeguarding blood stocks from risks posed by pathogens in the blood supply. ${ }^{(11)}$ On the other hand, the developed countries, and even some of the less developed countries with ageing populations, have to confront the decreasing numbers of eligible donors. In addition, older persons, who have higher risks of malignancies and chronic diseases, are more likely to require complex surgical interventions. ${ }^{(12)}$

\section{POORER OUTCOMES FOR PATIENTS WITH PREOPERATIVE ANAEMIA}

IDA is an independent risk factor for poor outcomes among patients scheduled for surgery. In a meta-analysis of observational studies, $39.1 \%$ of 949,445 patients undergoing surgery were found to be anaemic. ${ }^{(13)}$ This study and others (Table I) found preoperative anaemia to be associated with greater risks of transfusion, morbidity, mortality and increased length of hospital stay (LOS). ${ }^{(5,8,14-19)}$ Despite these risks and the exacerbation of anaemia by surgical blood loss, preoperative anaemia is deemed acceptable by many physicians. ${ }^{(20)}$ Consequently, many patients receive allogeneic $\mathrm{RBC}$ transfusions, which have remained the mainstay of perioperative anaemia management in many settings. This may be undesirable, as RBC transfusion is another

${ }^{1}$ Department of Anaesthesiology, ${ }^{2}$ Department of Haematology, Singapore General Hospital, Singapore, ${ }^{3}$ Department of Anaesthesia, Lyell McEwin Hospital, Discipline of Acute Care Medicine, University of Adelaide, Australia, ${ }^{4}$ Institute of Anaesthesiology, University Hospital Zurich, Switzerland, ${ }^{5}$ Faculty of Medicine, Dentistry and Health Sciences, University of Western Australia, ${ }^{6}$ Faculty of Health Sciences, Curtin University Western Australia, Australia, ${ }^{7}$ Division of Hematology-Oncology, Department of Medicine, Samsung Medical Center, Sungkyunkwan University School of Medicine, Seoul, ${ }^{8}$ Department of Cancer Control and Population Health, Graduate School of Cancer Science and Policy, National Cancer Center, South Korea, ${ }^{9}$ Department of Anesthesiology, Critical Care and Emergency, Angers University Hospital, France, ${ }^{10}$ Department of Obstetrics and Gynecology, Soonchunhyang University, South Korea, ${ }^{11}$ Department of Laboratory Medicine, Haematology Division, National University Hospital, Singapore, ${ }^{12}$ Department of Obstetrics and Gynaecology, Hospital Sultan Haji Ahmad Shah, Pahang, Malaysia, ${ }^{13}$ Division of Hip and Knee Surgery, ${ }^{14}$ Division of Musculoskeletal Oncology, National University Hospital, Singapore, ${ }^{15}$ Department of Laboratory Medicine, Inje University Ilsan Paik Hospital, South Korea

*All authors contributed equally in this work and are listed in alphabetical order.

Correspondence: A/Prof Bernd Froessler, Consultant Anaesthetist, Department of Anaesthesia, Lyell McEwin Hospital, University of Adelaide, Haydown Rd, Elizabeth Vale, SA 5112, Australia. Bernd.Froessler@sa.gov.au 
Table I. Outcomes in patients with preoperative anaemia.

\begin{tabular}{|c|c|c|c|}
\hline No. & Study, yr & Description & Results \\
\hline 1 & $\begin{array}{l}\text { Non-cardiac surgery, } \\
2018^{(15)}\end{array}$ & $\begin{array}{l}\text { Retrospective analysis of medical records of } \\
24,579 \text { patients aged } \geq 65 \text { years in Singapore } \\
\text { (January 2012-October 2016) }\end{array}$ & $\begin{array}{l}\text { Moderate/severe anaemia vs. normal: } \\
\uparrow 30 \text {-day mortality adjusted OR } 1.61 \text { ( } 95 \% \text { Cl 1.03-2.52); } \\
p=0.04\end{array}$ \\
\hline 2 & $\begin{array}{l}\text { Cardiac and non- } \\
\text { cardiac surgery, } \\
2017^{(8)}\end{array}$ & $\begin{array}{l}\text { Retrospective review of } 97,443 \text { patients in } \\
\text { Singapore (January } 2012-\text { October } 2016 \text { ) } \\
\text { Anaemia prevalence } 27.8 \% \text { (mild anaemia } \\
15.3 \% \text {, moderate anaemia } 12.0 \% \text {, severe } \\
\text { anaemia } 0.5 \% \text { ) }\end{array}$ & $\begin{array}{l}\text { Moderate/severe anaemia vs. normal: } \\
\uparrow 1 \text {-year mortality-adjusted HR } 2.86 \text { (95\% Cl 2.56-3.20) } \\
\text { Mild anaemia vs. normal: } \\
\uparrow 1 \text {-year mortality-adjusted HR } 1.98 \text { ( } 95 \% \mathrm{Cl} 1.77-2.21)\end{array}$ \\
\hline 3 & $\begin{array}{l}\text { Primary total knee } \\
\text { arthroplasty, } 2017^{(14)}\end{array}$ & $\begin{array}{l}\text { Retrospective study of 2,394 patients in } \\
\text { Singapore (January 2013-June 2014) } \\
\text { Anaemia prevalence } 23.7 \%: 403 \text { (16.8\%) with } \\
\text { mild anaemia and } 164 \text { (6.8\%) with moderate- } \\
\text { to-severe anaemia. }\end{array}$ & $\begin{array}{l}\text { Moderate-to-severe anaemia vs. normal: } \\
\uparrow \text { LOS OR } 3.22 \text { ( } 95 \% \text { Cl } 2.29-4.53) ; p<0.001 \\
\text { Mild anaemia vs. normal: } \\
\uparrow \text { LOS OR } 1.97 \text { ( } 95 \% \text { Cl 1.53-2.53); } p=0.001\end{array}$ \\
\hline 4 & $\begin{array}{l}\text { Orthopaedic surgery, } \\
2015^{(17)}\end{array}$ & $\begin{array}{l}\text { Observational study of 1,534 patients from } 17 \\
\text { centres in } 6 \text { European countries } \\
\text { Preoperative anaemia prevalence } 14.1 \% \text {, } \\
\text { postoperative anaemia prevalence } 85.8 \%\end{array}$ & $\begin{array}{l}\text { Preoperative anaemia vs. non-anaemic: } \\
\uparrow \text { Transfusion: } 14.8 \% \text { vs. } 2.8 \% \\
\text { - Units per patient: } 2.4(1.5) \text { vs. } 2.2(1.4) \\
\text { - Median time (min) to first intraoperative transfusion: } 130 \\
\quad \text { (range } 88-158 \text { ) vs. } 179 \text { (range } 135-256 \text { ); } p<0.001 \\
\uparrow \text { Postoperative complications: } 36.9 \% \text { vs. } 22.2 \% ; p=0.009\end{array}$ \\
\hline 5 & $\begin{array}{l}\text { Inpatient surgery, } \\
2014^{(16)}\end{array}$ & $\begin{array}{l}\text { Retrospective study of } 39,309 \text { patients in } 28 \\
\text { European nations }\end{array}$ & $\begin{array}{l}\text { Preoperative anaemia vs. normal } \mathrm{Hb} \text { concentrations: } \\
\uparrow \text { Mortality for severe (odds ratio } 2.82[95 \% \mathrm{Cl} 2.06-3.85]) \text { or } \\
\text { moderate }(1.99[95 \% \mathrm{Cl} 1.67-2.37] \text { ) anaemia higher than those } \\
\text { with normal preoperative } \mathrm{Hb} \text { concentrations } \\
\uparrow \mathrm{LOS}(\mathrm{p}<0.001) \\
\uparrow \text { Postoperative admission to intensive care }(\mathrm{p}<0.001)\end{array}$ \\
\hline 6 & $\begin{array}{l}\text { Gynaecological } \\
\text { surgery, } 2013^{(5)}\end{array}$ & $\begin{array}{l}\text { Retrospective study of } 843 \text { women in Western } \\
\text { Australia undergoing major gynaecological } \\
\text { surgery over a two-year period } \\
\text { Preoperative anaemia present in } 18.1 \% \text { of } \\
\text { women }\end{array}$ & $\begin{array}{l}\text { Preoperative anaemia vs. without anaemia: } \\
\uparrow \text { Transfusion: OR 5.74, } p<0.001 \\
\text { No increased complications or LOS }\end{array}$ \\
\hline 7 & $\begin{array}{l}\text { Major non-cardiac } \\
\text { surgery, } 2011^{(18)}\end{array}$ & $\begin{array}{l}\text { Retrospective study of } 227,425 \text { patients } \\
\text { undergoing major non-cardiac surgery in } \\
\text { United States, of whom } 69,229 \text { ( } 30.44 \%) \text { had } \\
\text { preoperative anaemia }\end{array}$ & $\begin{array}{l}\text { Preoperative anaemia vs. without anaemia: } \\
\uparrow \text { Postoperative mortality at } 30 \text { days: OR } 1.42 \text { (95\% Cl } \\
\text { 1.31-1.54) } \\
\text { Mild anaemia: OR } 1.41 \text { ( } 95 \% \text { Cl } 1.30-1.53) \\
\text { Moderate-to-severe anaemia: OR } 1.44 \text { ( } 95 \% \text { Cl 1.29-1.60) } \\
\uparrow \text { Composite postoperative morbidity at } 30 \text { days: OR } 1.35 \\
\text { (95\% Cl 1.30-1.40) } \\
\text { Mild anaemia: OR } 1.31 \text { (95\% Cl 1.26-1.36) } \\
\text { Moderate-to-severe anaemia: OR } 1.56(95 \% \text { Cl 1.47-1.66) }\end{array}$ \\
\hline 8 & $\begin{array}{l}\text { Hip and knee } \\
\text { surgery, } 2010^{(19)}\end{array}$ & $\begin{array}{l}\text { Systematic review of } 49 \text { published studies } \\
\text { in MEDLINE on anaemia (but not sickle cell) } \\
\text { in patients undergoing (1) total hip or knee } \\
\text { arthroplasty and (2) hip fracture surgery } \\
\text { Preoperative anaemia: } 24 \% \text { (hip/knee } \\
\text { arthroplasty) and } 44 \% \text { (hip fracture) }\end{array}$ & $\begin{array}{l}\text { Perioperative anaemia: } \\
\uparrow \text { Transfusion rate of } 45 \% \pm 25 \% \text { and } 44 \% \pm 15 \% \\
\uparrow \text { Postoperative anaemia: } 51 \% \text { and } 87 \% \\
\uparrow \text { Postoperative infections, poorer physical functioning and } \\
\text { recovery, and increased LOS and mortality }\end{array}$ \\
\hline
\end{tabular}

$\mathrm{Cl}$ : confidence interval; Hb: haemoglobin; HR: hazard ratio; LOS: length of hospital stay; OR: odds ratio; rHuEPO: recombinant human erythropoietin

independent risk factor for adverse outcomes such as infections and lung injury. ${ }^{(21)}$

Patient blood management (PBM) improves patient outcomes by applying evidence-based medical and surgical concepts across its three pillars, namely: Pillar 1 - optimise RBC mass; Pillar 2 minimise blood loss; and Pillar 3 - optimise anaemia tolerance of the patient to improve outcomes by clinically managing and preserving the patient's own blood. (22) In May 2010, the World Health Organization (WHO) formally recognised the importance of PBM and recommended it to its 193 member states. ${ }^{(23)}$ Under PBM Pillar 1, a key strategy for optimising the total RBC mass of patients undergoing surgery is to identify anaemia and treat its underlying causes preoperatively. ${ }^{(22)}$ For example, the Australian PBM guidelines recommend that doctors perform early evaluation and treatment of preoperative ID/IDA and its underlying causes as part of preparation for elective surgery. ${ }^{(24)}$ In most cases, preoperative IDA can be corrected with iron replacement therapy. ${ }^{(22)}$ 


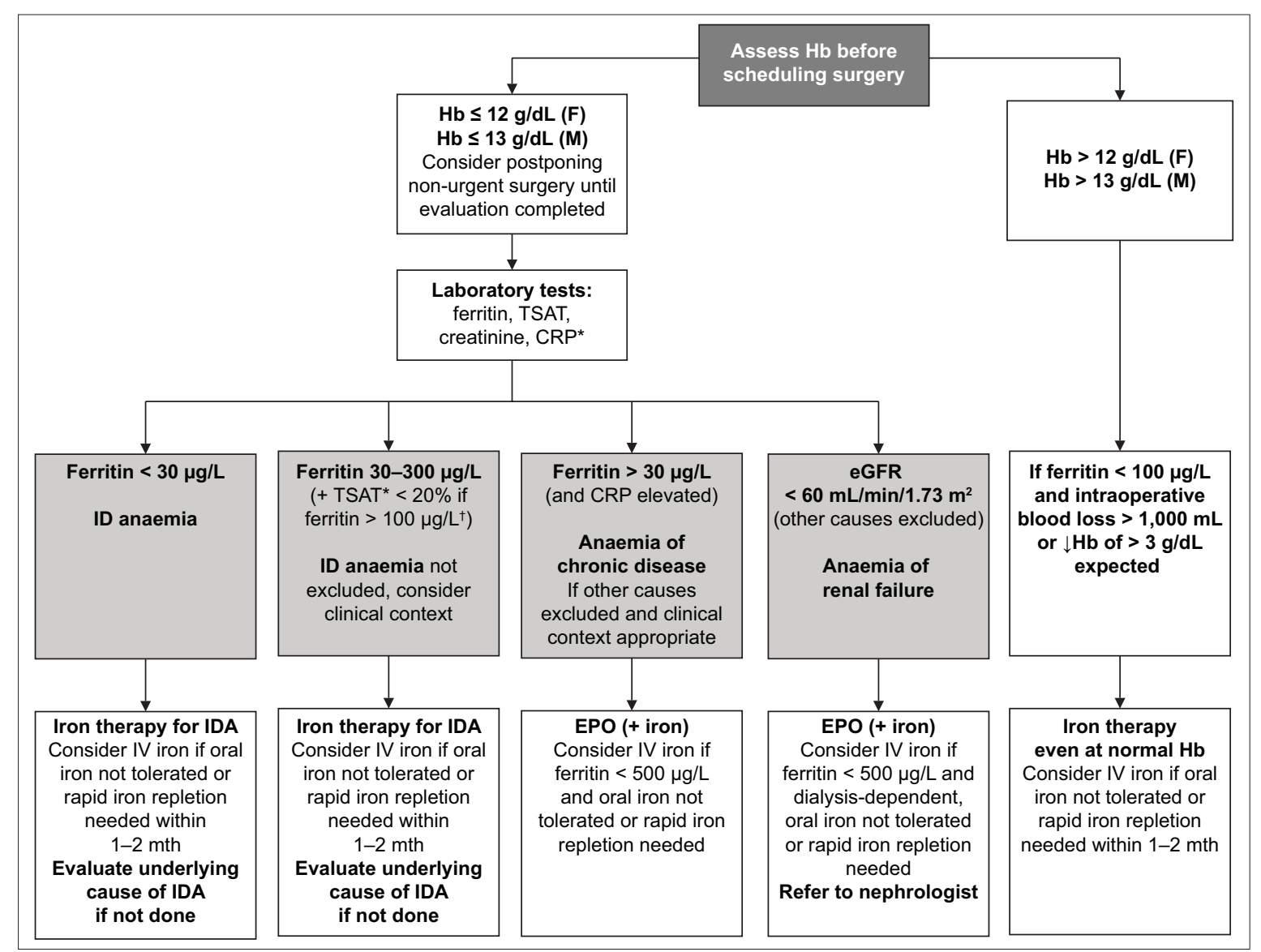

Fig. 1 Chart shows proposed algorithm to evaluate and treat perioperative anaemia. *If TSAT is unavailable, assess clinical context for conditions that may falsely elevate ferritin despite ID. If ferritin is $>100 \mu \mathrm{g} / \mathrm{L}$, TSAT < $20 \%$ is required to support diagnosis of IDA. If anaemia cannot be classified based on these, contact a haematologist. CRP: C-reactive protein; eGFR: estimated glomerular filtration rate; EPO: erythropoietin; F: female; Hb: haemoglobin; ID: iron deficiency; IDA: iron deficiency anaemia; IV: intravenous; M: male; TSAT: transferrin saturation

Successful PBM implementation in Western Australia was associated not only with reduced blood use (i.e. RBC units/ admission declined by $26 \%$ despite a $22 \%$ rise in admissions), ${ }^{(25)}$ but also significant reductions in preoperative anaemia, hospitalacquired complications, in-hospital mortality and LOS, with cost savings of > AUD 6 million per year. ${ }^{(26)}$ Such observations give weight to recommendations that elective surgeries be delayed until after anaemia correction. ${ }^{(27)}$ Despite these reasons and the availability of therapeutic strategies and pharmacologic interventions for reducing transfusion in the perioperative setting, PBM implementation has varied widely, even in Europe and Canada where PBM has been practised for many years. ${ }^{(28,29)}$

\section{CHALLENGES AND PROPOSED SOLUTIONS}

We examined PBM implementation in the Asia-Pacific countries of Australia, Malaysia, Republic of Korea and Singapore, discussing specific challenges of implementing PBM in these countries and suggesting potential solutions (Table II).

Postponement of surgery due to preoperative anaemia is usually not well received. Hospital administrators are concerned about optimising the utilisation of operating theatres, while physicians are resistant to changes to their clinical practice and concerned that delaying surgery may result in medical complications. Patients do not want to delay treatment, particularly for major illnesses, and are concerned about the cost and time needed for additional visits. Understanding that appropriate changes to current clinical practice can deliver better patient care and educating patients on the potential risks and benefits can help to overcome these challenges. Physicians should initiate anaemia investigations early, while patients should also be informed about the benefits of treating preoperative anaemia. We proposed an algorithm for the diagnosis and treatment of preoperative anaemia (Fig. 1).

Although formal iron studies are needed prior to iron therapy, some tests may not be readily available in resource-limited settings. We suggest that an assessment of ferritin together with clinical and patient-specific risk factors can identify most IDA cases. When IDA is detected early, oral iron supplementation is usually the first-line treatment. Some side effects from the use of oral iron include nausea, constipation and vomiting, ${ }^{(4)}$ which may lead to poor compliance to treatment. A systematic review has concluded that patients administered with intravenous (IV) iron experienced fewer gastrointestinal side effects compared to oral iron treatments. ${ }^{(30)}$

When time is limited, IV iron infusions can be used to rapidly and effectively replenish iron stores without compromising outcomes. ${ }^{(31)}$ However, in patients who urgently require reliable and rapid iron replacement, IV iron formulations such as iron sucrose, ferric gluconate, iron isomaltoside, low-molecular-weight 
Table II. Challenges to PBM implementation and proposed solutions.

\begin{tabular}{|c|c|c|}
\hline Challenge & Reason/perception & Recommendation \\
\hline $\begin{array}{l}\text { Physicians do not want to } \\
\text { postpone surgery in order to } \\
\text { treat anaemia }\end{array}$ & $\begin{array}{l}\text { They cannot make a patient wait for } 2-3 \text { weeks } \\
\text { to receive treatment for IDA. There is a fear of } \\
\text { complications from delayed surgery. }\end{array}$ & $\begin{array}{l}\text { Elective surgeries are usually scheduled in advance. The } \\
\text { referring primary care doctor could exclude anaemia } \\
\text { or treat the anaemia appropriately, if present, or the } \\
\text { surgeon could check for anaemia and treat as soon } \\
\text { as the patient is scheduled for surgery. This allows } \\
\text { sufficient time for investigation of the underlying cause } \\
\text { and appropriate management. }\end{array}$ \\
\hline Physician support & $\begin{array}{l}\text { Scepticism about efficacy of PBM, unease with } \\
\text { procedural scrutiny and an ingrained belief that } \\
\text { transfusion is safe. }\end{array}$ & $\begin{array}{l}\text { - Champions are needed within each discipline to } \\
\text { promote PBM from the patient safety perspective. } \\
\text { Interdisciplinary collaboration between various } \\
\text { stakeholder disciplines, such as the blood transfusion } \\
\text { committee working together with clinical } \\
\text { departments, is essential to effective implementation. } \\
\text { - Focus on efforts to implement PBM to provide the best } \\
\text { patient care rather than deliverables. A result-oriented } \\
\text { approach may invite resistance from physicians. }\end{array}$ \\
\hline $\begin{array}{l}\text { Limited time prior to surgery } \\
\text { for IDA correction. } \\
\text { Hospital administration } \\
\text { is concerned about } \\
\text { underutilisation of operating } \\
\text { theatre resources, as they } \\
\text { cannot be re-allocated at short } \\
\text { notice }\end{array}$ & $\begin{array}{l}\text { - Rescheduling a patient for surgery may create a } \\
\text { problem that the operating room time slot may } \\
\text { not be utilised by another patient due to the } \\
\text { short notice. } \\
\text { - For patients requiring chemotherapy and } \\
\text { surgery, there is a short window period prior to } \\
\text { surgery and } 2 \text { weeks may not be sufficient. }\end{array}$ & $\begin{array}{l}\text { - Iron studies can be performed at pre-admission } \\
\text { assessment and treatment given for underlying causes, } \\
\text { if needed, to avoid additional visits or rescheduling. } \\
\text { - Intravenous iron can be given on the day before } \\
\text { surgery or in operating rooms if time is severely } \\
\text { limited. Transfusion alone is insufficient to replenish } \\
\text { drained iron stores. }\end{array}$ \\
\hline $\begin{array}{l}\text { Additional patient visits for } \\
\text { iron supplementation result in } \\
\text { more costs for patient }\end{array}$ & $\begin{array}{l}\text { - Patients may be inconvenienced by additional } \\
\text { visits for iron studies and iron therapy, e.g. } \\
\text { patients who travel out of town for surgery. }\end{array}$ & $\begin{array}{l}\text { - Patients need to be informed about the risks of } \\
\text { preoperative anaemia; and that with treatment, he/she } \\
\text { can get home sooner after an operation. }\end{array}$ \\
\hline $\begin{array}{l}\text { Iron studies may add to the } \\
\text { cost of treatment }\end{array}$ & $\begin{array}{l}\text { - In some countries, the government bears the } \\
\text { cost of iron studies. Hospital administration } \\
\text { wants to see cost 'savings'. } \\
\text { - Blood is sometimes perceived to be readily } \\
\text { available at reasonable costs or even 'free'. }\end{array}$ & $\begin{array}{l}\text { - Help the government and hospital administration see } \\
\text { savings in terms of reduction in mortality, morbidity, } \\
\text { RBC transfusion and length of stay. } \\
\text { - The government or hospital may already be } \\
\text { subsidising the cost of blood. The actual cost of } \\
\text { providing blood should be made known. }\end{array}$ \\
\hline Availability of iron studies & $\begin{array}{l}\text { Some iron studies are not readily available at } \\
\text { hospitals. }\end{array}$ & $\begin{array}{l}\text { A ferritin assessment }(<100 \mu \mathrm{g} / \mathrm{L}) \text { should be sufficiently } \\
\text { sensitive to detect most IDA cases. Assess clinical and } \\
\text { patient-specific risk factors concurrently, as this also } \\
\text { helps to determine the likely cause and guide the } \\
\text { management of anaemia, especially in the absence of } \\
\text { resources for timely iron status evaluation. }\end{array}$ \\
\hline Other clinical considerations & $\begin{array}{l}\text { - In cancer patients with IDA ( } 5-7 \mathrm{~g} / \mathrm{dL}) \text {, ferritin } \\
\text { may be as high as } 500 \mathrm{\mu g} / \mathrm{L} \text {. } \\
\text { - For renal failure patients, it is not } \\
\text { recommended to raise } \mathrm{Hb} \text { above } 12 \mathrm{~g} / \mathrm{dL} \text { with } \\
\text { erythropoietin-stimulating agents, to reduce } \\
\text { risk of conditions such as stroke in non- } \\
\text { perioperative settings. } \\
\text { - Thalassaemia is prevalent in some parts of Asia } \\
\text { and iron supplementation would not help. }\end{array}$ & $\begin{array}{l}\text { There will always be exceptions to the rule. However, } \\
\text { the evidence is clear that perioperative iron therapy can } \\
\text { improve patient outcomes for patients with IDA. }\end{array}$ \\
\hline
\end{tabular}

Hb: haemoglobin; IDA: iron-deficiency anaemia; PBM: patient blood management; RBC: red blood cell

iron dextran (LMW-ID) or ferric carboxymaltose may be better suited, as they allow the slow release of iron with marginal or no toxicity-related adverse events. ${ }^{(4,32-34)}$ Incidence rates of adverse drug events were found to be lower with modern IV iron formulations, including LMW-ID, than with older high-molecularweight iron dextran preparations. ${ }^{(35)}$ Whereas iron sucrose and ferric gluconate infusions need to be administered across several sessions, iron isomaltoside, LMW-ID or ferric carboxymaltose, which bind iron more tightly, can replenish total iron deficit in one or two doses. ${ }^{(4,32)}$

IV iron is applicable in certain instances, including immediately before surgery, post trauma, and in cases of inability to tolerate or absorb oral iron, iron loss exceeding absorption rates, and late pregnancy. ${ }^{(4)}$ When there is insufficient 
Table III. Improvement in patient outcomes from perioperative IV iron therapy.

\begin{tabular}{|c|c|c|c|}
\hline No. & Study & Description & Results \\
\hline 1 & $\begin{array}{l}\text { Hip and knee } \\
\text { surgery, } 2016^{(37)}\end{array}$ & $\begin{array}{l}\text { Prospective observational, single-centre } \\
\text { study; } 367 \text { patients ( } 184 \text { before, } 183 \text { after) }\end{array}$ & $\begin{array}{l}\text { Before vs. after PBM using EPO and IV iron: } \\
\downarrow \text { Transfusion: } 3 \% \text { vs. } 13 \% ; p=0.0003 \\
\downarrow \text { Severe }(\mathrm{Hb}<10 \mathrm{~g} / \mathrm{dL} \text { ) anaemia at discharge } 14 \% \text { vs } 25 \% \text {; } \\
p=0.01, \text { TSAT } 11.0 \% \text { vs. } 0.1 \% ; \mathrm{p}<0.001\end{array}$ \\
\hline 2 & $\begin{array}{l}\text { Abdominal surgery, } \\
2016^{(38)}\end{array}$ & $\begin{array}{l}\mathrm{RCT} ; 72 \text { Australian patients with IDA were } \\
\text { randomly assigned to receive either (1) IV } \\
\text { iron or ( } 2 \text { ) usual care }\end{array}$ & $\begin{array}{l}\text { IV iron vs. usual care: } \\
\downarrow \text { Transfusion: } 12.5 \% \text { vs. } 31.3 \% \text { ( } 60 \% \text { reduction in red blood cell } \\
\text { transfusion) } \\
\downarrow \text { LOS: } 7.0 \text { days vs } 9.7 \text { days; } p=0.026 \\
\uparrow \text { Hb: improved by } 0.8 \mathrm{~g} / \mathrm{dL} \text { vs. } 0.1 \mathrm{~g} / \mathrm{dL} \text { by the day of } \\
\text { admission; } \mathrm{p}=0.01 \\
\uparrow \mathrm{Hb}: 1.9 \mathrm{~g} / \mathrm{dL} \text { vs } 0.9 \mathrm{~g} / \mathrm{dL} ; \mathrm{p}=0.01\end{array}$ \\
\hline 3 & Colon cancer, 2014 & $\begin{array}{l}\text { ROS; a total of } 266 \text { patients undergoing } \\
\text { elective surgery were included: (1) } 111 \\
\text { received FCM (median dose 1,000 mg) and } \\
\text { (2) } 155 \text { were non-IV iron subjects }\end{array}$ & $\begin{array}{l}\text { IV iron (FCM) vs. non-IV iron: } \\
\downarrow \text { Transfusion: } 9.9 \% \text { vs. } 38.7 \% ; \text { OR } 5.9 ; p<0.001 \\
\downarrow \text { LOS: } 8.4 \pm 6.8 \text { days vs. } 10.9 \pm 12.4 \text { days; } p<0.001 \\
\downarrow \% \text { with normalised } \mathrm{Hb}(30 \text { days post surgery): } 40.0 \% \text { vs. } \\
26.7 \% ; p<0.05 \\
\downarrow \text { Re-interventions and post-surgery complications: } 20.7 \% \text { vs. } \\
26.5 \% ; p=0.311 \\
\uparrow \mathrm{Hb}(\% \text { of responders): } \\
48.1 \% \text { vs. } 20.0 \% ; p<0.0001 \text { at admission } \\
80.0 \% \text { vs. } 48.9 \% ; p<0.0001 \text { at } 30 \text { days post surgery }\end{array}$ \\
\hline 4 & $\begin{array}{l}\text { Cardiac surgery, } \\
2015^{(40)}\end{array}$ & $\begin{array}{l}\text { ROS; } 2,662 \text { patients analysed, } 387 \text { in the pre- } \\
\text { PBM and 2,275 in the PBM epoch }\end{array}$ & $\begin{array}{l}\text { Post-PBM vs. pre-PBM: } \\
\downarrow \text { Transfusion: } 20.8 \% \text { vs. } 39.3 \% ; p<0.001 \\
\downarrow \text { LOS: } 10.4 \pm 8.0 \text { days vs. } 12.2 \pm 9.6 \text { days; } p<0.001 \\
\text { Hospital mortality rate and cerebral vascular accident incidence } \\
\text { remained unchanged }\end{array}$ \\
\hline 5 & $\begin{array}{l}\text { Orthopaedic surgery, } \\
2014^{(17)}\end{array}$ & $\begin{array}{l}\text { ROS; } 1,534 \text { patients undergoing major } \\
\text { elective hip, knee or spine surgery from } 17 \\
\text { centres in } 6 \text { European countries }\end{array}$ & $\begin{array}{l}\text { PBM }(n=7) \text { vs. non-PBM centres: } \\
\downarrow \text { Preoperative anaemia: } 8.0 \% \text { vs. } 18.5 \% ; p<0.001 \\
\uparrow \text { Ferritin: } 11.0 \% \text { vs. } 2.6 \% \text {, TSAT } 11.0 \% \text { vs. } 0.1 \% ; p<0.001\end{array}$ \\
\hline 6 & $\begin{array}{l}\text { Lower-limb } \\
\text { arthroplasty, 2014(41) }\end{array}$ & $\begin{array}{l}\text { ROS; } 2,547 \text { patients undergoing elective } \\
\text { lower-limb arthroplasty }(n=1,186) \text { or hip } \\
\text { fracture repair ( } n=1,361) \text { were compared; } \\
\text { patients received either }(1) \text { very-short-term } \\
\text { perioperative IV iron ( } 200-600 \text { mg, } n=1,538) \text {, } \\
\text { with or without recombinant human EPO } \\
(40,000 \text { IU), or ( } 2 \text { ) standard treatment } \\
(n=1,009)\end{array}$ & $\begin{array}{l}\text { Perioperative IV iron vs. standard treatment: } \\
\text { Hip fracture patients } \\
\downarrow \text { Transfusion: } 32.4 \% \text { vs. } 48.8 \% ; p=0.001 \\
\downarrow \text { LOS: } 11.9 \text { days vs. } 13.4 \text { days; } p=0.001 \\
\downarrow \text { PNI: } 10.7 \% \text { vs. } 26.9 \% ; p=0.001 \\
\downarrow 30 \text {-day mortality: } 4.8 \% \text { vs. } 9.4 \% ; p=0.003 \\
\text { Arthroplasty patients } \\
\downarrow \text { Transfusion: } 8.9 \% \text { vs. } 30.1 \% ; p=0.001 \\
\downarrow \text { LOS: } 8.4 \text { days vs. } 10.7 \text { days; } p=0.001 \\
\text { No differences in PNI rates and } 30 \text {-day mortality }\end{array}$ \\
\hline
\end{tabular}

EPO: erythropoietin; FCM: ferric carboxymaltose; Hb: haemoglobin; IDA: iron-deficiency anaemia; IV: intravenous; LOS: length of hospital stay; PBM: patient blood management; PNI: postoperative nosocomial infections; RCT: randomised controlled trial; ROS: retrospective observational study; TSAT: transferrin saturation

preoperative time (e.g. trauma and emergency surgical cases), postoperative IV iron therapy has also been shown to improve $\mathrm{Hb}$ recovery with fewer RBC transfusions, shorter LOS and, importantly, fewer infections. ${ }^{(36)}$ Clinical evidence (Table III) suggests that the use of IV iron increases the total RBC mass of patients undergoing surgery and improves outcomes. ${ }^{17,37-41)}$ Even in critically ill patients, early IV iron therapy raised discharge $\mathrm{Hb}$ levels despite lower transfusion triggers $(<7.5 \mathrm{~g} / \mathrm{dL})$ without compromising safety. ${ }^{(42)}$

\section{EXPERIENCE IN THE ASIA-PACIFIC}

PBM champions such as national health authorities and/or blood services, professional medical organisations, hospital administrators and, crucially, physicians are pivotal in promoting PBM implementation. They provide the strong leadership needed to sustainably establish effective programmes and create collaborative environments for healthcare professionals from the surgical, medical, transfusion medicine, and nursing departments, laboratory and pharmacy with guidelines, communication tools and education. ${ }^{(43)}$ We herein discuss examples from Australia and Singapore, the Republic of Korea and Malaysia and illustrate how different PBM champions can positively influence the practice of $\mathrm{PBM}$ in their respective countries.

\section{National health authorities}

In Australia, the National Blood Authority has published comprehensive PBM guidelines since 2012.(24) In addition, the Australian Commission on Safety and Quality in Health Care "requires that blood and blood product policies, procedures and/or protocols are consistent with national evidence-based 
guidelines for pre-transfusion practices, prescribing and clinical use of blood and blood products" (Action 7.1.1). ${ }^{(24)}$ From mid-2010 to mid-2015, the number of RBC units issued saw a $15.8 \%$ reduction. ${ }^{(44)}$ A multidisciplinary National Patient Blood Management Collaborative, led by the Department of Health, Australia, was established in 2015 to further promote appropriate care for patients and reduce exposure to transfusion. 12 hospitals were selected and supported with federal funding. They identified and implemented changes in preoperative practice in areas that were at risk for anaemia. Monthly data for 8,758 procedures (May 2015-September 2016) showed that $98 \%$ of patients were assessed for preoperative anaemia, an increase from 90\%; $71 \%$ had their anaemia managed, up from 28\%; 90\% were assessed for ID, from 25\%; and 53\% had their ID managed, from 39\%. ${ }^{(44)}$

In Singapore, the Blood Services Group of the Health Sciences Authority, a statutory board of the Ministry of Health, supplies blood nationwide. With an ageing population $(11.8 \%$ were aged $>65$ years) and life expectancy of 82.7 years, blood demand is expected to increase even as eligible donors decrease. ${ }^{(45)}$ To mitigate this, the Ministry of Health and Blood Services Group have actively promoted PBM at public hospitals since 2013. Regular national audits of PBM-related efforts have been performed since 2017 to promote appropriate clinical indications for RBC transfusion and preoperative anaemia screening for elective surgeries. We herein describe these PBM efforts at two major public hospitals: National University Hospital and Singapore General Hospital, Singapore.

National University Hospital's anaemia clinic was started in 2014 and is integral to its PBM programme. A preliminary survey showed that $23 \%$ of patients had preoperative anaemia, with $57 \%$ requiring transfusion subsequently, compared to $18 \%$ for patients without anaemia. Surgeons were encouraged to refer patients for anaemia management if patients had $\mathrm{Hb}<10 \mathrm{~g} / \mathrm{dL}$, any degree of anaemia and poor cardiopulmonary reserve; or when the surgery had a potential for high blood loss. IDA management was initiated with oral iron if ferritin $<100 \mu \mathrm{g} / \mathrm{L}(<200 \mu \mathrm{g} / \mathrm{L}$ in non-dialysis-dependent chronic kidney disease) and transferrin saturation $<20 \%$. IV iron was given as soon as was feasible if there was no response after two weeks, intolerance to oral iron or the surgery was scheduled within four weeks; or after surgery if therapy was not started earlier. Erythropoietin was used on an individualised basis, e.g. chronic kidney disease Stage III/V or chemotherapy-induced anaemia in a palliative setting.

At Singapore General Hospital, formal PBM implementation was started in 2013 as part of the national initiative. The hospital had a number of existing measures to support PBM, i.e. a multidisciplinary blood transfusion committee, transfusion guidelines and an early preoperative anaemia assessment clinic. In August 2017, a preoperative anaemia management pathway was instituted in which anaemic patients undergoing surgery were given either oral iron (ferrous fumarate) or single-dose IV iron (ferric carboxymaltose) depending on the severity of anaemia, invasiveness of surgery and time available for optimisation. Mandatory documentation of indications for RBC transfusion was also instituted, while inappropriate indications generated alerts via the computerised physician order entry (CPOE) system. A preliminary one-month audit of the system showed that $21 \%$ of CPOEs generated alerts for inappropriate indications and were subsequently cancelled.

\section{Professional medical organisations}

The Korean Research Society of Transfusion Alternatives of the Republic of Korea began promoting PBM in 2006. In 2014, the Korean Patient Blood Management (KPBM) Research Group was formed to further promote greater PBM use. Its active participation saw PBM included in the Korean Transfusion Guidelines of 2016 for the first time. In 2016, the KPBM organised a new steering committee comprising $>40$ leading physicians from various specialties to promote PBM in their respective clinical fields.

The Korean Society of Blood Transfusion, representing practitioners in blood banking and transfusion medicine, including laboratory physicians, haematologists and anaesthetists, supported PBM with the creation of its PBM committee in 2016. A KPBM survey showed that $70 \%-80 \%$ of practising surgeons supported the use of PBM and had held special PBM symposia within their respective society meetings. A number of Korean hospitals that adopted PBM as part of their clinical practice have already demonstrated its benefits in improved postoperative $\mathrm{Hb}$ levels, with reductions in transfusions (Table IV). ${ }^{(46-49)}$

\section{Physicians}

In Malaysia, PBM is practised at the local level (e.g. maternal and fetal medicine department at the Sultan Haji Ahmad Shah Hospital, Pahang, Malaysia). Postpartum haemorrhage (PPH) remains one of the main causes of maternal mortality in Malaysia. High parity is common among local women and access to affordable healthcare remains a key challenge. Women at high risk of anaemia are tested for $\mathrm{Hb}$ levels and ferritin in early pregnancy. Patients who are found to be iron-deficient are treated with low-dose elemental iron (20-80 mg daily); those with anaemia are given higher-dose elemental iron orally (100-200 mg daily) and their response is monitored. In this resource-constrained setting, IV iron is used when time is limited or when oral iron is ineffective or poorly tolerated. Despite its efficacy, IV iron is used sparingly due to the higher cost of iron sucrose compared to oral iron. Other practical measures to minimise the risk of anaemia included providing dietary advice and advice on increasing the interval period between pregnancies as well as treating comorbidities.

For $\mathrm{PPH}$, patients who were not actively bleeding were managed in the following ways based on their $\mathrm{Hb}$ levels: (a) $>9 \mathrm{~g} / \mathrm{L}$ - transfusion was deemed inappropriate and discouraged; (b) 7-9 g/L - transfusion was based on the need to relieve clinical signs and symptoms of anaemia, and the availability of anaemia treatment, expected delivery date and risk factors for haemorrhage; and (b) $<7 \mathrm{~g} / \mathrm{L}-$ transfusion could be used but might not be required for well-compensated patients, or other therapies were available. When indicated, a single RBC unit was given followed by clinical assessment to determine further need. 
Table IV. Studies documenting benefits of PBM in Asia-Pacific countries.

\begin{tabular}{|c|c|c|c|}
\hline Yr & Country, study & Description & Results \\
\hline 2016 & $\begin{array}{l}\text { Australia, abdominal } \\
\text { surgery }^{(38)}\end{array}$ & $\begin{array}{l}\text { RCT; } 72 \text { patients with IDA were randomly assigned } \\
\text { to receive either ( } 1 \text { ) IV iron or ( } 2 \text { ) usual care }\end{array}$ & $\begin{array}{l}\text { IV iron vs. usual care: } \\
\downarrow \text { Transfusion: } 12.5 \% \text { vs. } 31.3 \% \text { ( } 60 \% \text { reduction in RBC } \\
\text { transfusion) } \\
\downarrow \text { LOS: } 7.0 \text { days vs. } 9.7 \text { days; } p=0.026 \\
\uparrow \text { Hb: improved by } 0.8 \mathrm{~g} / \mathrm{dL} \text { vs. } 0.1 \mathrm{~g} / \mathrm{dL} \text { by the day of } \\
\text { admission; } \mathrm{p}=0.01 \\
\uparrow \mathrm{Hb}: 1.9 \mathrm{~g} / \mathrm{dL} \text { vs. } 0.9 \mathrm{~g} / \mathrm{dL} ; \mathrm{p}=0.01\end{array}$ \\
\hline 2016 & $\begin{array}{l}\text { Australia, intensive } \\
\text { care }^{(42)}\end{array}$ & $\begin{array}{l}\text { RCT; of } 140 \text { patients enrolled, (1) } 70 \text { were assigned } \\
\text { to IV iron and (2) } 70 \text { to placebo }\end{array}$ & $\begin{array}{l}\text { IV iron vs. placebo: } \\
\downarrow \text { Transfusion: } 97 \text { vs. } 136 \text { red blood cell units yielding an } \\
\text { incidence rate ratio of } 0.71 \text { ( } 95 \% \mathrm{Cl} 0.43-1.18 \text { ); } p=0.19 \\
\uparrow \text { Median } \mathrm{Hb} \text { at discharge: } 107 \text { (IQR } 97-115) \mathrm{g} / \mathrm{L} \text { vs. } 100 \\
\text { (IQR } 89-111) \mathrm{g} / \mathrm{L} ; \mathrm{p}=0.02 \\
\text { No significant difference between the groups in any } \\
\text { safety outcome }\end{array}$ \\
\hline 2015 & $\begin{array}{l}\text { Republic of Korea, } \\
\text { obstetrics and } \\
\text { gynaecology }{ }^{(46)}\end{array}$ & $\begin{array}{l}\text { Retrospective analysis over a } 10 \text {-year time frame } \\
\text { of severely anaemic women }(\mathrm{Hb}<50 \mathrm{~g} / \mathrm{L}) \text { with } \\
\text { benign conditions who had requested not to } \\
\text { receive a blood transfusion and given IV iron } \\
\text { and EPO instead. Women were analysed in two } \\
\text { groups: }(1) \text { a gynaecologic ( } \mathrm{gyn}, \mathrm{n}=12) \text { and }(2) \text { an } \\
\text { obstetric }(\mathrm{ob}, \mathrm{n}=7 \text { ) population. }\end{array}$ & $\begin{array}{l}\text { Mean age } 35.8 \pm 10.2 \mathrm{yr} \\
\text { With IV iron, EPO and no transfusion, } \uparrow \text { mean } \mathrm{Hb} \\
\text { concentration } 41.3 \pm 9.7 \mathrm{~g} / \mathrm{L} \text { (gyn) and } 36.0 \pm 8.9 \mathrm{~g} / \mathrm{L} \\
\text { (ob) to } 67.3 \pm 14.3 \mathrm{~g} / \mathrm{L} \text { and } 73.1 \pm 6.9 \mathrm{~g} / \mathrm{L} \text {, respectively, } \\
\text { by the time of hospital discharge } \\
\text { No deaths or other serious complications }\end{array}$ \\
\hline 2014 & $\begin{array}{l}\text { Republic of Korea, } \\
\text { gastric cancer }{ }^{(49)}\end{array}$ & $\begin{array}{l}\text { Case-control study of } 2078 \text { gastric cancer patients } \\
\text { who underwent surgery between February } \\
2007 \text { and August 2009, } 368 \text { patients developed } \\
\text { postoperative anaemia (Hb level }<9 \mathrm{~g} / \mathrm{dL} \text { ) } \\
\text { within the first postoperative week. Patients } \\
\text { requiring transfusions were excluded. (1) IV iron } \\
\text { was administered to } 63 \text { patients (iron group). ( } 2 \text { ) } \\
60 \text { patients were observed without treatment } \\
\text { (observation group). }\end{array}$ & $\begin{array}{l}\text { IV iron vs. observation group } \\
\uparrow \text { Change in Hb level: } 0.648 \pm 0.054 \mathrm{~g} / \mathrm{dL} \text { vs. } 0.349 \pm \\
0.038 \mathrm{~g} / \mathrm{dL} ; \mathrm{p}<0.001 \\
\uparrow \mathrm{Hb} \text { Level } 1 \text { and } 3 \mathrm{mth} \text { postoperatively: } 10.7 \pm 1.3 \mathrm{~g} / \mathrm{dL} \\
\text { to } 11.9 \pm 1.3 \mathrm{~g} / \mathrm{dL} ; \mathrm{p}=0.033 \mathrm{vs.} 10.1 \pm 1.0 \mathrm{~g} / \mathrm{dL} \text { to } \\
10.8 \pm 1.4 \mathrm{~g} / \mathrm{dL} ; \mathrm{p}<0.001 \\
\uparrow \text { Postoperative LOS: } 10.5 \pm 6.8 \text { days vs. } 7.6 \pm 5.5 \text { days; } \\
\mathrm{p}=0.011 \\
\text { No significant differences in major and surgical } \\
\text { complications between the groups ( } 6.3 \% \text { vs. } 13.3 \% \text {, } \\
p=0.192 ; 9.5 \% \text { vs. } 3.3 \%, p=0.164)\end{array}$ \\
\hline 2011 & $\begin{array}{l}\text { Republic of Korea, } \\
\text { bilateral total } \\
\text { knee replacement } \\
\text { arthroplasty }{ }^{(47)}\end{array}$ & $\begin{array}{l}\text { RCT; } 108 \text { iron-deficient patients were randomly } \\
\text { assigned to: (1) Group IE ( } 200 \mathrm{mg} \text { of iron } \\
\text { sucrose intravenously over } 1 \mathrm{hr} \text { and 3,000 IU of } \\
\text { recombinant human EPO-beta subcutaneously } \\
\text { during operation and during the postoperative } \\
\text { period if the } \mathrm{Hb} \text { level was } 70-80 \mathrm{~g} / \mathrm{L} \text { ) or (2) Group } \\
\mathrm{C} \text { (control) }\end{array}$ & $\begin{array}{l}\text { IV iron (Group IE) vs. control (Group C): } \\
\downarrow \text { Transfusion: } 20.4 \% \text { vs. } 53.7 \% ; p=0.011 \\
\downarrow \text { Mean number of RBC units transfused: } 0.2 \pm 0.5 \text { vs. } 0.8 \\
\pm 0.8 ; p=0.005 \\
\uparrow \text { Postoperative iron, ferritin, and transferrin saturation } \\
\text { levels were significantly higher }\end{array}$ \\
\hline 2011 & $\begin{array}{l}\text { Republic of Korea, } \\
\text { valvular heart } \\
\text { surgery }^{(48)}\end{array}$ & $\begin{array}{l}\text { RCT; } 74 \text { patients with preoperative anaemia } \\
\text { were randomly allocated to either the (1) EPO } \\
\text { group ( } 500 \mathrm{IU} / \mathrm{kg} \text { EPO and } 200 \mathrm{mg} \text { iron sucrose } \\
\text { intravenously } 1 \text { day before the surgery) or ( } 2 \text { ) } \\
\text { control group with equivalent volume of normal } \\
\text { saline }\end{array}$ & $\begin{array}{l}\text { IV iron vs. control: } \\
\downarrow \text { Transfusion: } 22 \text { patients }(59 \%) \text { vs. } 32 \text { patients }(86 \%) ; \\
p=0.009 \\
\downarrow \text { Mean no. of units of packed erythrocytes transfused } \\
\text { per patient: }(3.3 \pm 2.2 \text { units/patient vs. } 1.0 \pm 1.1 \text { units/ } \\
\text { patient; } p=0.001 \\
\uparrow \text { Reticulocyte count was significantly greater on } \\
\text { postoperative Days } 4(p=0.001) \text { and } 7(p=0.001)\end{array}$ \\
\hline
\end{tabular}

Cl: confidence interval; EPO: erythropoietin; Hb: haemoglobin; IDA: iron deficiency anaemia; IQR: interquartile range; IV: intravenous; LOS: length of hospital stay; PPA: postpartum anaemia; RBC: red blood cell; RCT: randomised controlled trial

\section{BENEFITS OF PBM PILLAR 1}

Our article has described the practice of PBM in four different healthcare settings. Although these examples are certainly not exhaustive, they illustrate a range of implementation approaches that can be applied in both developed and developing countries. As we and others have noted, there is an urgent need for action. ${ }^{(50)}$ The anaemia burden in the Asia-Pacific region is high, with growing numbers of elderly patients who are more likely to be anaemic. ${ }^{(2)}$ Without PBM, a third to half $(30 \%-54 \%)^{(16,18,47)}$ of patients undergoing surgery could require transfusion, increasing the demand for blood and potentially leading to poorer patient outcomes. Shrinking blood donor pools puts a strain on the blood supply system and may result in cancellation or postponement of elective surgery in some countries. 
On the other hand, studies in the region have shown that the application of PBM Pillar 1 has led to shorter LOS, improved $\mathrm{Hb} /$ ferritin levels and fewer adverse events, besides reduced transfusion rates (Table IV). ${ }^{(38,42,46-49)}$ Implementation of PBM also has a significant positive impact on healthcare costs. A 2012 study of $>100,000$ patients in the canton of Zurich, Switzerland, showed a $27 \%$ reduction in RBC transfusion in the first year of implementation with direct savings of USD 2.0 million on blood products alone. ${ }^{(43,51)}$ In Australia, the National Blood Authority estimated that a $5 \%$ reduction in RBC use would save AUD 14.6 million nationally. ${ }^{(51)}$ Cost savings from the use of IV iron to treat preoperative IDA were reported at USD 730 per patient (Singapore) ${ }^{(52)}$ and USD 22,192 per quality-adjusted life-year for patients with chronic heart failure (Republic of Korea) ${ }^{(53)}$ in 2014. There is also the intangible cost of RBC transfusion-associated adverse outcomes and prolonged LOS. ${ }^{(54)}$

While each country may face different challenges in implementing PBM, the concept is applicable everywhere. Notwithstanding its urgency, the implementation process should proceed stepwise in a manner that is appropriate to the healthcare setting and acceptable to stakeholders. Post implementation, it is also essential to apply quality assurance measures of good benchmarking, monitoring and feedback, ${ }^{(54)}$ and demonstrate improved patient outcomes and safety benefits. Although this review presents PBM Pillar 1 for perioperative settings, the same principles of implementation can be extended to the other two pillars of PBM and to the non-surgical fields of medicine.

\section{CONCLUSION}

IDA is common and it is an independent modifiable risk factor for patient outcomes. Physicians and patients need to be aware of the risks of preoperative anaemia and appreciate that early treatment of IDA preoperatively can help to improve patient safety and outcomes. The most feasible way of implementing PBM is to start with small steps and expand efforts over time. Getting PBM Pillar 1 right by using iron replacement therapy to preoperatively optimise red cell mass in patients with IDA is a sensible first step to take when embarking on PBM implementation, regardless of the healthcare setting.

\section{AUTHOR CONTRIBUTIONS}

Froessler B and Spahn DR co-chaired the PBM workshop and presented data on current Pillar 1 practice. Froessler B presented data for Australia; Lim KKC for Malaysia; Ang AL, Lee SY and Singh G for Singapore; and Kim YW for the Republic of Korea. All of the authors participated in the workshop discussion, contributed equally to the drafting, reviewed the manuscript and approved its submission.

\section{ACKNOWLEDGEMENTS AND DISCLOSURE OF COMPETING INTERESTS}

This manuscript was developed following a workshop supported by Vifor Pharma Asia Pacific and Vifor (International) AG in October 2016. Vifor Pharma Asia Pacific provided support in respect of publication costs but had no influence on the content of the work. Abdullah HR received travel support, speaking honoraria and research grant support from Vifor Pharma. Lee SY, Lim KKC and Um TH received travel support from Vifor Pharma to attend the workshop. Ang AL and Lee JJ have received speaker or lecture honoraria in the past and travel support from Vifor Pharma. Froessler B has received lecture honoraria or travel support in the past five years from the New South Wales Department of Health; South Australia Department of Health; Australian Red Cross Blood Service; National Blood Authority, Australia; Vifor Pharma Ltd, Glattbrugg, Switzerland; Fresenius Kabi GmbH, Bad Homburg, Germany; and CSL Behring Biotherapies for Life ${ }^{\mathrm{TM}}$ Victoria, Australia. Hofmann A has received honoraria and/or travel support for professional services related to programme implementation, health economic analyses, outcomes research and lecturing from Vifor Fresenius Medical Care Renal Pharma Ltd, Vifor Pharma AG, Switzerland. Kim YW has received a research grant from Vifor Pharma and JW Pharmaceutical and travel support from Vifor Pharma. Spahn DR's academic department is receiving grant support from the Swiss National Science Foundation, Berne, Switzerland; the Ministry of Health (Gesundheitsdirektion) of the Canton of Zurich, Switzerland for Highly Specialized Medicine; the Swiss Society of Anesthesiology and Reanimation (SGAR), Berne, Switzerland; the Swiss Foundation for Anesthesia Research, Zurich, Switzerland; CSL Behring, Berne, Switzerland; Vifor SA, Villars-sur-Glâne, Switzerland. Spahn DR is co-chair of the ABC-Trauma Faculty, sponsored by unrestricted educational grants from Novo Nordisk Health Care AG, Zurich, Switzerland; CSL Behring GmbH, Marburg, Germany; LFB Biomédicaments, Courtaboeuf Cedex, France; and Octapharma AG, Lachen, Switzerland. Spahn DR has received honoraria or travel support for consulting or lecturing from: Danube University of Krems, Austria; US Department of Defense, Washington, USA; European Society of Anesthesiology, Brussels, Belgium; Korean Society for Patient Blood Management, Seoul, Korea; Korean Society of Anesthesiologists, Seoul, Korea; Baxter AG, Volketswil, Switzerland; Baxter S.p.A., Roma, Italy; Bayer AG, Zürich, Switzerland; Bayer Pharma AG, Berlin, Germany; B Braun Melsungen AG, Melsungen, Germany; Boehringer Ingelheim $\mathrm{GmbH}$, Basel, Switzerland; Bristol-Myers-Squibb, Rueil-Malmaison Cedex, France, and Baar, Switzerland; CSL Behring GmbH, Hattersheim am Main, Germany, and Berne, Switzerland; Celgene International II Sàrl, Couvet, Switzerland; Curacyte AG, Munich, Germany; Daiichi Sankyo AG, Thalwil, Switzerland; GlaxoSmithKline $\mathrm{GmbH}$ \& Co KG, Hamburg, Germany; Haemonetics, Braintree, MA, USA; Instrumentation Laboratory (Werfen), Bedford, MA, USA; LFB Biomédicaments, Courtaboeuf Cedex, France; Merck Sharp \& Dohme, Kenilworth, New Jersey, USA; Octapharma AG, Lachen, Switzerland; Organon AG, Pfäffikon/SZ, Switzerland; PAION Deutschland $\mathrm{GmbH}$, Aachen, Germany; Pharmacosmos A/S, Holbaek, Denmark; Photonics Healthcare B.V., Utrecht, Netherlands; Roche Diagnostics International Ltd, Reinach, Switzerland; Roche Pharma AG, Reinach, Switzerland; Sarstedt AG \& Co, Sevelen, Switzerland, and Nümbrecht, Germany; Schering-Plough International, Inc, Kenilworth, New Jersey, 
USA; Tem International GmbH, Munich, Germany; Verum Diagnostica $\mathrm{GmbH}$, Munich, Germany; Vifor Pharma, Munich, Germany, Vienna, Austria, and Villars-sur-Glâne, Switzerland; and Vifor (International) AG, St Gallen, Switzerland. Lasocki S has received consultancy fees from Vifor Pharma and hospice and travel support from Sandoz.

The authors also acknowledge editorial and manuscriptdrafting support funded by Vifor Pharma Asia-Pacific, provided by Sen-Kwan Tay and Geraldine Toh, Tech Observer Asia-Pacific Pte Ltd; and would like to thank Sze Min Loh, Vifor Pharma AsiaPacific, for critical reading and discussion.

\section{REFERENCES}

1. GBD 2015 Disease and Injury Incidence and Prevalence Collaborators. Global, regional, and national incidence, prevalence, and years lived with disability for 310 diseases and injuries, 1990-2015: a systematic analysis for the Global Burden of Disease Study 2015. Lancet 2016; 388:1545-602.

2. Kassebaum NJ, Jasrasaria R, Naghavi M, et al. A systematic analysis of global anemia burden from 1990 to 2010. Blood 2014; 123:615-24.

3. World Health Organization. Haemoglobin concentrations for the diagnosis of anaemia and assessment of severity. Available at: https://www.who.int/vmnis/ indicators/haemoglobin/en/. Accessed October 20, 2017.

4. Camaschella C. Iron-deficiency anemia. N Engl J Med 2015; 372:1832-43.

5. Browning RM, Trentino K, Nathan EA, Hashemi N; Western Australian Patient Blood Management Program. Preoperative anaemia is common in patients undergoing major gynaecological surgery and is associated with a fivefold increased risk of transfusion. Aust N Z J Obstet Gynaecol 2012; 52:455-9.

6. Kassebaum NJ, GBD 2013 Anemia Collaborators. The global burden of anemia. Hematol Oncol Clin North Am 2016; 30:247-308.

7. Lee JO, Lee JH, Ahn S, et al. Prevalence and risk factors for iron deficiency anemia in the Korean population: results of the fifth Korea National Health and Nutrition Examination Survey. J Korean Med Sci 2014; 29:224-9.

8. Sim YE, Wee HE, Ang AL, et al. Prevalence of preoperative anemia, abnormal mean corpuscular volume and red cell distribution width among surgical patients in Singapore, and their influence on one year mortality. PLoS One 2017; 12:e0182543.

9. World Health Organization. Blood safety: key global fact and figures in 2011 Available at: https://www.who.int/worldblooddonorday/media/who_blood_ safety_factsheet_2011.pdf. Accessed October 20, 2017.

10. Schantz-Dunn J, M N. The use of blood in obstetrics and gynecology in the developing world. Rev Obstet Gynecol 2011; 4:86-91.

11. Garraud O, Filho LA, Laperche S, Tayou-Tagny C, Pozzetto B. The infectious risks in blood transfusion as of today - A no black and white situation. Presse Med 2016; 45(7-8 Pt 2):e303-11.

12. Farmer SL, Towler SC, Leahy MF, Hofmann A. Drivers for change: Western Australia Patient Blood Management Program (WA PBMP), World Health Assembly (WHA) and Advisory Committee on Blood Safety and Availability (ACBSA). Best Pract Res Clin Anaesthesiol 2013; 27:43-58.

13. Fowler AJ, Ahmad T, Phull MK, et al. Meta-analysis of the association between preoperative anaemia and mortality after surgery. Br J Surg 2015; 102:1314-24.

14. Abdullah HR, Sim YE, Hao Y, et al. Association between preoperative anaemia with length of hospital stay among patients undergoing primary total knee arthroplasty in Singapore: a single-centre retrospective study. BMJ Open 2017; 7:e016403.

15. Abdullah HR, Sim YE, Sim YT, et al. Preoperative Red Cell Distribution Width and 30-day mortality in older patients undergoing non-cardiac surgery: a retrospective cohort observational study. Sci Rep 2018; 8:6226.

16. Baron DM, Hochrieser H, Posch M, et al; European Surgical Outcomes Study (EuSOS) group for Trials Groups of European Society of Intensive Care Medicine; European Society of Anaesthesiology. Preoperative anaemia is associated with poor clinical outcome in non-cardiac surgery patients. Br J Anaesth 2014; 113:416-23.

17. Lasocki S, Krauspe R, von Heymann C, et al. PREPARE: the prevalence of perioperative anaemia and need for patient blood management in elective orthopaedic surgery: a multicentre, observational study. Eur J Anaesthesiol 2015; 32:160-7.

18. Musallam KM, Tamim HM, Richards T, et al. Preoperative anaemia and postoperative outcomes in non-cardiac surgery: a retrospective cohort study. Lancet 2011; 378:1396-407.

19. Spahn DR. Anemia and patient blood management in hip and knee surgery: a systematic review of the literature. Anesthesiology 2010; 113:482-95.

20. Isbister JP, Shander A, Spahn DR, et al. Adverse blood transfusion outcomes: establishing causation. Transfus Med Rev 2011; 25:89-101.
21. Spahn DR, Goodnough LT. Alternatives to blood transfusion. Lancet 2013; 381:1855-65.

22. Isbister JP. The three-pillar matrix of patient blood management--an overview. Best Pract Res Clin Anaesthesiol 2013; 27:69-84.

23. 63rd World Health Assembly. Resolution WHA63.12: Availability, safety and quality of blood products. 21 May 2010. Available at: http://apps.who.int/gb/ ebwha/pdf_files/WHA63/A63_R12-en.pdf. Accessed August 15, 2018.

24. National Blood Authority, Australia. National Standard for Blood and Blood Products Safety and Quality. Available at: https://www.blood.gov.au/nationalstandard. Accessed August 16, 2017.

25. Leahy MF, Roberts H, Mukhtar SA, et al; Western Australian Patient Blood Management Program. A pragmatic approach to embedding patient blood management in a tertiary hospital. Transfusion 2014; 54:1133-45.

26. Leahy MF, Hofmann A, Towler S, et al. Improved outcomes and reduced costs associated with a health-system-wide patient blood management program: a retrospective observational study in four major adult tertiary-care hospitals. Transfusion 2017; 57:1347-58.

27. Klein AA, Arnold P, Bingham RM, et al. AAGBI guidelines: the use of blood components and their alternatives 2016. Anaesthesia 2016; 71:829-42.

28. Baron DM, Metnitz PG, Fellinger T, et al. Evaluation of clinical practice in perioperative patient blood management. Br J Anaesth 2016; 117:610-6.

29. Van der Linden P, Hardy JF. Implementation of patient blood management remains extremely variable in Europe and Canada: the NATA benchmark project: an observational study. Eur J Anaesthesiol 2016; 33:913-21.

30. Avni T, Bieber A, Grossman A, et al. The safety of intravenous iron preparations: systematic review and meta-analysis. Mayo Clin Proc 2015; 90:12-23.

31. Bhandari S. Beyond efficacy and safety: the need for convenient and costeffective iron therapy in health care. NDT Plus 2011; 4(Suppl 1):i14-i19.

32. Auerbach M, Deloughery T. Single-dose intravenous iron for iron deficiency: a new paradigm. Hematology Am Soc Hematol Educ Program 2016; 2016:57-66.

33. Auerbach M, Goodnough LT, Shander A. Iron: the new advances in therapy. Best Pract Res Clin Anaesthesiol 2013; 27:131-40.

34. Rognoni C, Venturini S, Meregaglia M, Marmifero M, Tarricone R. Efficacy and safety of ferric carboxymaltose and other formulations in iron-deficient patients: a systematic review and network meta-analysis of randomised controlled trials. Clin Drug Investig 2016; 36:177-94.

35. Chertow GM, Mason PD, Vaage-Nilsen O, Ahlmén J. Update on adverse drug events associated with parenteral iron. Nephrol Dial Transplant 2006; 21:378-82.

36. Khalafallah AA, Yan C, Al-Badri R, et al. Intravenous ferric carboxymaltose versus standard care in the management of postoperative anaemia: a prospective, open-label, randomised controlled trial. Lancet Haematol 2016; 3:e415-25.

37. Rineau E, Chaudet A, Chassier C, Bizot P, Lasocki S. Implementing a blood management protocol during the entire perioperative period allows a reduction in transfusion rate in major orthopedic surgery: a before-after study. Transfusion 2016; 56:673-81.

38. Froessler B, Palm P, Weber I, et al. The important role for intravenous iron in perioperative patient blood management in major abdominal surgery: a randomized controlled trial. Ann Surg 2016; 264:41-6.

39. Calleja JL, Delgado S, del Val A, et al. Ferric carboxymaltose reduces transfusions and hospital stay in patients with colon cancer and anemia. Int J Colorectal Dis 2016; 31:543-51.

40. Gross I, Seifert B, Hofmann A, Spahn DR. Patient blood management in cardiac surgery results in fewer transfusions and better outcome. Transfusion 2015; 55:1075-81.

41. Muñoz M, Gómez-Ramirez S, Cuenca J, et al. Very-short-term perioperative intravenous iron administration and postoperative outcome in major orthopedic surgery: a pooled analysis of observational data from 2547 patients. Transfusion 2014; 54:289-99

42. IRONMAN Investigators, Litton E, Baker S, et al. Intravenous iron or placebo for anaemia in intensive care: the IRONMAN multicentre randomized blinded trial: a randomized trial of IV iron in critical illness. Intensive Care Med 2016; 42:1715-22.

43. Mbanya D. Barriers and enablers to introducing comprehensive patient blood management in the hospital. Biologicals 2012; 40:205-8.

44. Australian Commission on Safety and Quality in Healthcare. The National Patient Blood Management Collaborative. Available at: https://www.safetyandquality. gov.au/national-priorities/pbm-collaborative/. Accessed August 16, 2016.

45. Ministry of Health, Singapore. Population and vital statistics. Available at: https:// www.moh.gov.sg/resources-statistics/singapore-health-facts/population-andvital-statistics. Accessed August 16, 2017.

46. Lee ES, Kim MJ, Park BR, et al. Avoiding unnecessary blood transfusions in women with profound anaemia. Aust N Z J Obstet Gynaecol 2015; 55:262-7.

47. Na HS, Shin SY, Hwang JY, et al. Effects of intravenous iron combined with low-dose recombinant human erythropoietin on transfusion requirements in iron-deficient patients undergoing bilateral total knee replacement arthroplasty. Transfusion 2011; 51:118-24.

48. Yoo YC, Shim JK, Kim JC, et al. Effect of single recombinant human erythropoietin injection on transfusion requirements in preoperatively anemic patients undergoing valvular heart surgery. Anesthesiology 2011; 115:929-37. 
49. Yoon HM, Kim YW, Nam BH, et al. Intravenous iron supplementation may be superior to observation in acute isovolemic anemia after gastrectomy for cancer. World J Gastroenterol 2014; 20:1852-7.

50. Muñoz M, Acheson AG, Auerbach M, et al. International consensus statement on the peri-operative management of anaemia and iron deficiency. Anaesthesia 2017; 72:233-47.

51. Mehra T, Seifert B, Bravo-Reiter S, et al. Implementation of a patient blood management monitoring and feedback program significantly reduces transfusions and costs. Transfusion 2015; 55:2807-15
52. Ong DEH, Hadi F, Stevens V. Health economic evaluation comparing IV iron ferric carboxymaltose, iron sucrose and blood transfusion for treatment of patients with iron deficiency anemia (IDA) in Singapore. Value Health 2014; 17:A784.

53. Lim EA, Sohn HS, Lee $\mathrm{H}$, Choi SE. Cost-utility of ferric carboxymaltose (Ferinject( $\mathbb{B})$ for iron-deficiency anemia patients with chronic heart failure in South Korea. Cost Eff Resour Alloc 2014; 12:19.

54. Hofmann A, Ozawa S, Farrugia A, Farmer SL, Shander A. Economic considerations on transfusion medicine and patient blood management. Best Pract Res Clin Anaesthesiol 2013; 27:59-68. 